\title{
Long QT Syndrome and Electrical Storm: Is Implanted Cardiac Defibrillator the Final Destination in Long QT Syndrome Management?
}

\author{
Ali A. Al-Mossawi ${ }^{a}$, Kasim A. Ismaila, Zainab A. Dakhil ${ }^{b}$ \\ a Cardiology Department, Ibn Al-Bitar Cardiac Center, Baghdad, Iraq \\ ${ }^{b}$ Al-Kindy College of Medicine, Baghdad University, Baghdad, Iraq
}

\section{ARTICLE INFO}

Article history:

Submitted: 22. 5. 2020

Revised: 31. 7. 2020

Accepted: 2. 8. 2020

Available online: 22. 10. 2020

\section{Klíčová slova:}

Arytmogenní syndromy

Mladý jedinec

Psychosociální podpora

Rozvíjející se ekonomika

Sympatektomie

Keywords:

Arrhythmogenic syndromes

Emerging country

ICD storm

Psychosocial support

Sympathectomy

Young

\section{SOUHRN}

Elektrická bouře představuje život ohrožující stav, který je u pacientů s implantovanými defibrilátory definován jako tři nebo více správně vyhodnocené epizody komorové arytmie v předchozích 24 hodinách, které následně vedou k vyslání výbojů defibrilátorem. Hlavní úlohu při spuštění a udržování komorové arytmie hraje stimulace sympatiku. Popisujeme prípad pacienta ze země s rozvíjející se ekonomikou, u něhož byla stanovena diagnóza syndromu dlouhého intervalu QT, byl mu implantován defibrilátor a při vyšetření u něj byla zjištěna elektrická bouře. Tento př́pad ukazuje na náročné situace, s nimiž se setkává v každodenní praxi lékař pečující o obyvatele zemí s rozvíjející se ekonomikou.

(c) 2020, ČKS.

\section{Background}

Electrical storm is a life-threatening medical emergency and in the context of implantable cardiac defibrillator (ICD) it is defined as three or more appropriate detections of ventricular arrhythmia in prior 24 hours leading to ICD shocks. ${ }^{1,2}$ Sympathetic stimulation is the forefront player for initiation and maintenance of ventricular arrhythmia especially in long QT (LQT) syndromes. . $^{2,3}$ We are reporting a case of congenital LQT syndrome who underwent ICD implantation and now presented with ICD storm.

\section{Case report}

A 17-year-old girl with history of implantable cardiac defibrillator (ICD-VR) implanted for long QT syndrome due to recurrent syncope 10 years ago, she underwent a box replacement for end of life battery 5 years ago, her family history was remarkable for a brother who died suddenly while asleep at age of 13 years. Due to non-availability of the test, she was not genetically classified after being diagnosed of LQT syndrome. The patient was kept on propranolol tab $10 \mathrm{mg}$ thrice daily. Over the last three months she had been admitted frequently for electrical storms. This time again; she was presented with recurrent ICD shocks (more than 6 shocks) over the last 24 hours, all preceded by emotional stress and palpitation, she was admitted to cardiac care unit for further evaluation and management, where electrocardiogram showed long QT interval of 581, as seen in Fig. 1, and ventricular ectopic (PVC), monitor in cardiac care unit showed ventricular tachycardia/ventricular fibrillation episodes treated appropriately by ICD shocks, this was further confirmed by de-

Address: Zainab A. Dakhil, FIBMS Cardiol, FIBMS (Med.), CABM, D.M (Med.), D.M Chest diseases, MBChB, Al-Kindy College of Medicine, Baghdad University, Baghdad, Iraq, e-mail: stethoscope.med@gmail.com

DOI: $10.33678 /$ cor.2020.076

Please cite this article as: Al-Mossawi AA, Ismail KA, Dakhil ZA. Long QT Syndrome and Electrical Storm: Is Implanted Cardiac Defibrillator the Final Destination in Long QT Syndrome Management? Cor Vasa 2020;62:483-485. 


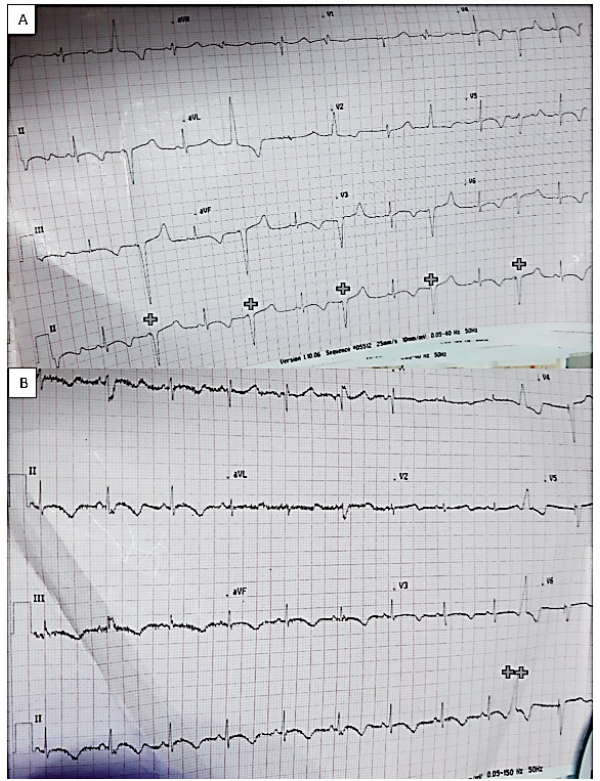

Fig. 1 - (A) ECG shows long QT with every other beat pacing (+) with prominent pacing spike. (B) ECG with long QT (QTC = 581 msec.) and PVC (++), there is diffuse deep T wave inversion (no evidence of structural heart disease like cardiomyopathy or ventricular hypertrophy on echocardiography).

vice programming. During admission; on daily follow-up; the patient was anxious and tearful and more emotional distress was evident with each new ICD shock which further exacerbated her ventricular arrhythmia. Her blood tests including potassium, magnesium, and calcium were all normal, the patient was kept on magnesium and lidocaine infusions in addition to propranolol tab $40 \mathrm{mg}$ thrice daily (considering the important role of beta-blockers in decreasing arrhythmia burden), ${ }^{4}$ still she had frequent ICD discharges until propranolol increased up to $40 \mathrm{mg}$ four times daily (maximum tolerated dose as further increase caused hypotension), the patient at this dose had no further shocks, magnesium infusion was stopped then lidocaine infusion was also stopped, ultimately patient was on propranolol only with no more ICD shocks.

Considering patient's impaired quality of life and psychological burden of ICD events both on her and her family and being an adolescent who seeks a normal functioning life and who can face daily stress and challenges especially in her age which might further exacerbate her ventricular arrhythmia, in response; the treating team discussed additional measures that should be undertaken to prevent further episodes of ICD storm especially the episodes were usually triggered by intense emotions, so sympathectomy was recommended according to latest guidelines, ${ }^{5}$ but unfortunately it was unavailable locally, socioeconomic status of patient deprived her from further attempt to pursue centres abroad for the procedure. Mexiletine also suggested as one of the effective drugs in LQT syndrome which can decrease burden of ventricular arrhythmia in such patients, ${ }^{1,5}$ again the drug was not offered in our markets. Finally, patient was kept on betablockers and followed thoroughly on outpatient basis, she mentioned one month later that she had ICD shocks but only occasionally.

\section{Discussion}

This case highlights important; yet overlooked aspects in managing patients with arrhythmogenic syndromes who are treated with implanted cardiac defibrillators especially in emerging countries; mainly the role of invasive procedures like left cardiac sympathectomy and PVC ablation in this population, not mentioning the vital role of psychosocial support for these patients.

LQT syndrome is characterized by prolonged ventricular repolarization with susceptibility to develop VT (usually polymorphic VT) which can degenerate into VF, patients can be presented with syncope or SCD. ${ }^{6}$ Congenital LQT syndromes are classified into 13 subtypes according to specific genetic mutations, with LQT1 being the most common subtype. ${ }^{7}$ Despite that genetic testing is the gold standard for subtype recognition, there are certain clinical and electrocardiographic findings that can suggest the subtype in the absence of genotype analysis. For example, the trigger for cardiac event is mainly by exercise, swimming and sympathetic stimulation in LQT1 syndrome, emotional stress or sudden auditory stimuli (like alarm-clock), or less commonly during sleep or exercise, or during the postpartum period in LQT2 syndrome, while cardiac events in LQT3 syndrome usually occur during rest or bradycardia. ${ }^{8-11}$ ECG also can help in differentiation between LQT subtypes as following: :-9 $^{-9}$

- $\quad$ LQT1: There are broad based, peak T waves producing QT prolongation

- $\quad$ LQT2: There are notched or bifid T waves.

- LQT3: The late appearance of the T wave after long ST segment will produce long QT interval.

Interestingly, our patient had broad based T wave with generalized T wave inversion and prolonged QT, these changes along with history of arrhythmia triggering by emotional stress can suggest LQT1 syndrome, despite such ECG changes are not classical in long QT syndromes, there is a report of LQT syndrome case series ${ }^{12}$ which described $T$ wave changes like flat $T$ wave, biphasic $T$ wave or deep symmetrical T wave inversions in chest lead $V_{1}-V_{4^{\prime}}$ however, up to our knowledge, there had been no case report of long QT syndrome with such generalized deep symmetrical T wave inversions involving most ECG leads in the absence of associated cardiomyopathies.

The cornerstone management in high-risk LQT syndrome are beta-blockers and ICD implantation. ${ }^{13}$ Betablockers decreased cardiac events in this population by $50 \%$, they are also effective in decreasing exercise triggered cardiac events, ${ }^{14-17}$ however, cardiac events can still occur while patients on beta-blockers, particularly in symptomatic individuals as it was reported that $32 \%$ of symptomatic persons will have a cardiac event over the next 5 years, and $14 \%$ of patients with a prior cardiac arrest will have a recurrence within 5 years. ${ }^{15,18}$

Another therapeutic option in LQT syndrome is left cardiac sympathetic denervation which is used in refractory ventricular arrhythmias, it is a rarely performed procedure despite effectiveness, ${ }^{19}$ it can be considered in long QT syndrome patients who suffer from ICD events despite beta-blockers therapy. ${ }^{5,19}$ Sympathectomy is a treatment modality that can minimize the arrhythmia burden in LQTS patients, but not obliterate it, with low complica- 
tion rate. ${ }^{20}$ This option received class I recommendation in cases of recurrent appropriate ICD shocks in long QT syndrome after intensification of medical treatment like beta-blockers or in cases of intolerance to medical therapy. ${ }^{5}$

With recent progress of mapping techniques and subsequent catheter ablation; there has been broadening in its indications to further include the channelopathies like LQT syndromes, yet it is crucial to notice that ablation of PVC triggers is not curative and not an alternative for ICD insertion in high-risk LQT syndrome cases. ${ }^{13}$

Current case report highlights other critical point which is the role of psychosocial management and mental health care in young patients with arrhythmogenic syndromes who are treated with ICD, as in emerging countries this service is not provided for those patients despite its necessity especially that patients with arrhythmogenic syndromes are usually young and seek normal quality of life just like their peers. ICD shocks were reported to decrease psychological function and impair quality of life, so ICD benefit in decreasing morbidity can be partially waived with recurrent shocks which can cause depression, anxiety disorders and mood disturbances rendering patients at most need for psychological support. ${ }^{21,22}$

This case report is a reflection of current status of management of patients with arrhythmogenic syndromes and a call for action to healthcare providers, decision makers and stakeholders to make sympathectomy a feasible option in cardiac facilities and to include psychosocial services in the specialized cardiac centres especially if we consider the high volume of device implantation procedures in young patients that conducted in these centres.

\section{Conclusion}

It is of utmost importance that we consider what is the next step after ICD implantation, and we should seriously realize that ICD is not the final destination in managing young population with arrhythmogenic syndromes, it is only the first step of a long journey that we will walk through side by side with our patients, so we need to make it a fruitful prosperous journey with least suffering as possible.

\section{Acknowledgements}

None.

\section{Conflicts of interest}

None.

\section{Funding}

None.

\section{Ethical statement}

The authors assert that all procedures contributing to this work comply with the ethical standards of the relevant national Iraqi guidelines and with the Helsinki Declaration of 1975, as revised in 2008, and has been approved by the ethical and scientific committee in Ibn Al-Bitar Cardiac Center. Informed consent to publish the case was obtained from the patient and her parent.

\section{References}

1. Christos K, Konstantinos T, Georgios G, et al. Electrical Storm: Current Evidence, Clinical Implications, and Future Perspectives. Curr Cardiol Rep 2019;21:96.

2. Philippon F, Sterns L, Nery P, et al. Management of Implantable Cardioverter Defibrillator Recipients: Care Beyond Guidelines. Can J Cardiol 2017:33:977-990.

3. Hendriks A, Szili-Torok T. Editor's Choice - The treatment of electrical storm: an educational review. Eur Heart J Acute Cardiovasc Care 2018;7:478-483.

4. Connolly SJ, Dorian P, Roberts RS, et al. Comparison of beta-blockers, amiodarone plus beta blockers, or sotalol for prevention of shocks from implantable cardioverter defibrillators: the OPTIC Study: a randomized trial. JAMA 2006;295:165-171.

5. Al-Khatib S, Stevenson W, Ackerman M, et al. 2017 AHA/ACC/ HRS Guideline for Management of Patients with Ventricular Arrhythmias and the Prevention of Sudden Cardiac Death: Executive Summary, A Report of the American College of Cardiology/American Heart Association Task Force on Clinical Practice Guidelines and the Heart Rhythm Society. J Am Coll Cardiol 2018;72:e91-e220.

6. Skinner JR. Guidelines for the diagnosis and management of familial long QT syndrome. Heart, Lung Circ 2007;16:22-24.

7. Brenyo AJ, Huang DT, Aktas MK. Congenital long and short QT syndromes. Cardiology 2012;122:237-247.

8. Medeiros-Domingo A, Iturralde-Torres $\mathrm{P}$, Ackerman MJ. Clinical and genetic characteristics of long QT syndrome. Rev Esp Cardiol (English Edition) 2007;60:739-752.

9. Zhang L, Timothy KW, Vincent GM, et al. Spectrum of ST-T-wave patterns and repolarization parameters in congenital long-QT syndrome: ECG findings identify genotypes. Circulation 2000;102:2849-2855.

10. Schwartz PJ, Priori SG, Spazzolini C, et al. Genotype-phenotype correlation in the long-QT yndrome: gene-specific triggers for life-threatening arrhythmias. Circulation 2001;103:89-95.

11. Zareba W. Genotype-specific ECG patterns in long QT syndrome. J Electrocardiol 2006;39:S101-S106.

12. Thu-Thuy LT, Hayano M, Yano K. Long-term follow-up of notched T waves in female patients with LQT2 (HERG) mutations. Jap Heart J 2004;45:243-250.

13. Yap J, Tan VH, Hsu LF, Liew R. Catheter ablation of ventricular fibrillation storm in a long QT syndrome genotype carrier with normal QT interval. Singapore Med J 2013;54:e1-e4.

14. Goldenberg I, Moss AJ, Peterson DR, et al. Risk factors for aborted cardiac arrest and sudden cardiac death in children with the congenital long-QT syndrome. Circulation 2008; 117:2184-2191.

15. Cho Y. Management of patients with long QT syndrome. Korean Circ J 2016:46:747-752.

16. Goldenberg I, Thottathil P, Lopes CM, et al. Trigger-specific ion channel mechanisms, risk factors, and response to therapy in type 1 long QT syndrome. Heart Rhythm 2012;9:49-56.

17. Kim JA, Lopes CM, Moss AJ, et al. Trigger-specific risk factors and response to therapy in long QT syndrome type 2 . Heart Rhythm 2010;7:1797-1805.

18. Moss AJ, Zareba W, Hall WJ, et al. Effectiveness and limitations of beta-blocker therapy in congenital long-QT syndrome. Circulation 2000;101:616-623.

19. Hocini M, Pison L, Proclemer A, et al. Diagnosis and management of patients with inherited arrhythmia syndromes in Europe: results of the European Heart Rhythm Association Survey. Europace 2014;16:600-603.

20. Achilleas A, Lawrence $D$, Davide $P$, et al. The role of Sympathectomy in long QT syndrome. Thorac Dis 2017;9:33943397.

21. Sears S, Conti J. Understanding Implantable Cardioverter Defibrillator Shocks and Storms: Medical and Psychosocial Considerations for Research and Clinical Care. Clin Cardiol 2003;26:107-111.

22. Anderson $\mathrm{H}$, Medford $\mathrm{B}$, Ackerman $\mathrm{M}$, Marked, transient, emotion-triggered QT accentuation in an adolescent female with type 1 long QT syndrome. Cardiol Young 2015;25:376-379. 